\title{
Perancangan Aplikasi Inventaris Gudang Menggunakan Bahasa Program PHP dan Database MySQL Berbasis WEB
}

\author{
Aldie Lukman Al Hakim ${ }^{1}$, Ilham Maulana ${ }^{2}$, Itmamul Wafa ${ }^{3}$, Yoga Koswara ${ }^{4}$, Yulianti ${ }^{5}$ \\ Teknik Informatika, Universitas Pamulang, Tangerang Selatan, Indonesia, 15417 \\ email: ${ }^{1}$ aldielukman712@gmail.com, ${ }^{2}$ ielmaulana.ilham1234@gmail.com, ${ }^{3}$ itmamulwafa09@gmail.com, \\ ${ }^{4}$ yogakoswara08@gmail.com, ${ }^{5}$ yulianti@unpam.ac.id \\ Submitted Date: November $17^{\text {th }}, 2020$ \\ Revised Date: March 31 $1^{\text {st }}, 2021$ \\ Reviewed Date: February $04^{\text {th }}, 2021$ \\ Accepted Date: April 01 ${ }^{\text {st }}, 2021$
}

\section{Abstract}

$C V$. Gema Insani Press is a company that operates in the printing of books, calendars, books and so on. To support the production of goods, the role of the inventory warehouse is very important. The problem that often occurs is that the recording of incoming and outgoing goods is still using traditional methods using software from Microsoft Excel so that there is often an error in the amount of materials that makes the stock insufficient when needed. Therefore an application is needed that can help record incoming and outgoing goods from the warehouse so that the existing stock of materials is the same as the data entered. The development of this application uses a method that is often used, namely the waterfall method and the programming language used is PHP using MySQL as the database center. This application is can make it easier to record items in the warehouse.

Keywords: Design, Inventory, MySQL, PHP, Web based

\section{Abstract}

CV. Gema Insani Press merupakan perusahaan yang berjalan di bidang percetakan buku, kalender, kitab dan lain sebagainya. Untuk menunjang berjalannya produksi barang, peran gudang persediaan sangat penting. Masalah yang sering terjadi adalah pencatatan masuk dan keluar barang masih menggunakan metode tradisional dengan menggunakan catatan manual dan software dari microsoft excel sehingga sering terjadi kesalahan jumlah bahan yang membuat stok tidak tercukupi saat dibutuhkan. Oleh karena itu diperlukan sebuah aplikasi yang bisa membantu mencatat barang masuk dan barang keluar dari gudang sehingga stok bahan yang ada sama dengan data yang dimasukkan. Pengembangan aplikasi ini menggunakan metode yang sering digunakan yaitu metode air terjun dan bahasa pemrograman yang dipakai adalah PHP dengan menggunakan MySQL sebagai pusat datanya. Aplikasi ini dapat mempermudah pencatatan barang yang ada di gudang.

Kata Kunci: Berbasis Web, Inventaris, MySQL, Perancangan, PHP

\section{Pendahuluan}

Pentingnya topik berkembangan teknologi yang sangat cepat. Di buktikan dengan adanya banyak inovasi yang telah dirancang dan dibangun saat ini. Berkembangnya teknologi yang cukup mulai waktu ke waktu membuat suatu pekerjaan menjadi lebih efisien. Mayoritas perusahaan masih belum menggunakan sistem terkomputerisasi atau belum efektif dalam penggunaannya, seperti dalam menginput atau pencatatan ketersediaan bahan, mengupdate jumlah atau stok barang masuk serta stok barang keluar, yang mengakibatkan belum tercapainya efektivitas dan kemudahan dalam mengelola dengan baik dan tepat.

Sistem saat ini aplikasi inventaris barang atau aplikasi persediaan barang begitu penting bagi sebuah perusahaan, mengingat perusahaan yang bergerak saat ini banyak yang beralih dalam bidang produksi. Sehingga, pengelolaan data barang dan bahan produksi menjadi sangat penting dalam ketersediaan barang.

Tetapi, pada saat ini pencatatan masih manual dan hanya menggunakan Ms excel dasar sehingga beberapa hal kurang efektif dalam pengelolaan data inventaris tersebut dan 
mengakibatkan kerugian karena anggaran belanja yang ditanggung dalam ketersediaan barang dan tidak validnya data dan lamanya proses pembagian info antar bagian gudang dan pembelian bahan persediaan (Syarif \& Mustagfirin, 2019).

CV. Gema Insani Press merupakan perusahaan yang berjalan di bidang percetakan buku, kalender, kitab dan lain sebagainya. Untuk menunjang berjalannya produksi barang, peran gudang persediaan sangat penting (Agusvianto, 2017). Masalah yang sering terjadi adalah pencatatan masuk dan keluar barang jumlah barang (Sari \& Nuari, 2017). Maka kami mengembangkan aplikasi inventaris gudang untuk memperbaiki pencatatan keluar masuk barang sehingga jumlah barang yang ada serta data yang terdapat di sistem komputer sama. Hal ini akan membuat pemesanan barang atau bahan sesuai dengan kebutuhan produksi.

Metode usulan untuk menyelesaikan masalah yang digunakan adalah metode WaterFall. Metode ini kami gunakan karena pengembangan aplikasi ini akan bertahap dari pengecekan data dan informasi yang ada hingga penyesuaian data dan fisik yang valid. Sehingga mengurangi kesalahan yang mungkin terlewat jika tidak diperiksa satu persatu.

Dalam penerapan atau pelaksanaan proses pengembangan software ini, ada beberapa proses yang harus dilalui untuk mengoptimalkan kinerja aplikasi ini, diantara ialah melakukan stock opname gudang. Stock Opname adalah menghitung jumlah fisik bahan yang ada pada gudang dan mencatatnya (Khasani \& Surjawan, 2016). Hal ini dilakukan untuk menyamakan jumlah fisik yang dengan jumlah yang ada pada data komputer. Setelah data disamakan, data dimasukkan ke dalam aplikasi yang dikembangkan., pengarahan pada staff admin gudang serta pengguna bahan untuk selalu menggunakan sistem aplikasi yang ada dalam proses keluar masuk bahan dari gudang, sehingga tidak ada bahan yang keluar masuk tanpa melalui perhitungan sistem, dan melakukan stock opname tiap bulan untuk memastikan jumlah bahan tetap sama dengan data yang ada pada sistem aplikasi yang ada.

\section{Metodologi}

Model kami gunakan dalam pembuatan aplikasi web ini adalah metode waterfall. Metode waterfall dipilih karena metode waterfall dapat menghasilkan software yang matang (mature).
Metode waterfall merupakan metode pengembangan perangkat lunak yang sistematik dan terstruktur (Samsudin, Indrawan, \& Mulyati, 2020). Metode ini menggambarkan pendekatan sistematis berurutan pada pengembangan software, mulai dari:

- Kebutuhan

- Rancangan

- Model

- Konstruksi

- Penyerahan sistem ke User

- perawatan sistem

Pada tahapan-tahapan ini dianggap pas karena apilkasi yang kami buat masih terhubung dengan bagaimana aplikasi yang dibuat nantinya serta siapa saja yang akan mengguakan aplikasi ini.

Tahapan-tahapan yang ada pada metode waterfall adalah:

A. Perencanaan (Planning)

Pada tahap ini kami mencari tahu mengenai informasi yang berhubungan dengan aplikasi ini. Mulai dari fungsi aplikasi, waktu pembuatan aplikasi, hingga pengetahuan pengguna tentang komputer sehingga aplikasi yang dibuat bisa sesuai dengan kebutuhan pengguna dan bisa dimanfaatkan dengan baik.

B. Analisis (Analysis)

Pada tahan analisis kami akan membandingkan aplikasi yang telah berjalan dengan aplikasi yang akan dibuat nantinya, dari segi kinerja aplikasi, Kendali, efisiensi, ekonomi dan layanan aplikasi.

C. Desain (Design)

Tahap ini bertujuan untuk memberikan gambaran lengkap tentang apa yang harus dikerjakan dan bagaimana tampilan dari sebuah sistem yang diinginkan. Sehingga membantu menspesifikan kebutuhan sistem, juga mendefinisikan arsitektur sistem yang akan dibuat secara keseluruhan.

D. Implementasi (Implementation)

Dalam tahap ini, kami mulai membuat aplikasi berdasarkan hal yang telah dibahas di atas dan menyesuaikan pembuatan sesuai dengan rancangan yang sudah ada. Dalam tahap ini juga dilakukan pemeriksaan

E. Pengujian (Testing) 
Untuk menjamin kualitas sistem/aplikasi yang dikembangkan harus melalui tahap pengujian (Pratala, Asyer, Prayudi, \& Saifudin, 2020). Pengujian merupakan suatu rangkaian aktivitas yang terencana dan sistematis untuk menguji atau mengevaluasi kebenaran fungsi aplikasi berdasarkan desain kasus uji (test case) yang spesifik (Yulistina, Nurmala, Supriawan, Juni, \& Saifudin, 2020). Pengujian terhadap perangkat lunak sangat penting dilakukan dengan tujuan untuk memberikan jaminan kualitas perangkat lunak yang dihasilkan agar bebas dari terjadinya kesalahan (Debiyanti, Sutrisna, Budrio, Kamal, \& Yulianti, 2020).

Pada tahap pengujian, aplikasi yang telah dibuat akan diuji coba sistem kerjanya. Apakah sudah sesuai fungsi yang direncanakan dan apakah masih ada masalah dalam proses berjalannya aplikasi. Sehingga bisa langsung diperbaiki sebelum benar-benar dipakai dalam sistem yang sebenarnya

F. Perawatan (Maintenance)

Pada operasi dan perawatan. Software yang sudah melewati tahapan tahapan sebelumnya dioperasikan oleh penggunanya. Pada tahapan ini dilakukan pemeliharaan seperti update sistem jika terjadi bug pada saat penggunaan

\subsection{Aktifitas Perencanaan (Planning)}

Beberapa aktifitas yang dilakukan pada tahap perencanaan (planning) adalah:

A. Identifikasi Fungsi Aplikasi

Di era modern seperti ini sebuah aplikasi berbasis web merupakan aplikasi yang masih bisa dikembangkan terus menerus mengikuti software dan hardware yang terus berkembang. Aplikasi ini juga mendukung kinerja admin gudang dan pemakai barang dengan kemudahan pencatatan dan mengurangi waktu administratif.

B. Analisa Organisasi

Dalam proses berjalannya aplikasi ini, peran bagian admin dan pemasok barang atau pemakai barang sangat berpengaruh terhadap jalannya aplikasi dan validnya data barang dan fisik yang ada. Jika ada kurangnya laporan barang masuk atau keluar pada bagian adminitratif tentu akan mempengaruhi keseimbangan data yang ada. Koordinasi antar bagian sangat diperlukan dalam pengoperasian aplikasi ini.

C. Analisis Kelayakan Ekonomi

Demi mendapat hasil yang baik dimasa depan, potensi/kemampuan manusia dan juga modal dibutuhkan dalam perancangan sistem guna sebagai salah satu bentuk penanaman modal. Untuk menganalisis kelayakan dalam bentuk ekonomi digunakan kalkulasi analisis anggaran dan manfaat. Tujuan dari analisis anggaran dan manfaat ialah guna menginformasikan bayangan awal kepada pengguna, apa manfaat yang di dapatkan dari sebuah sistem lebih perlu dibanding dengan dana yang dikeluarkan. Pada analysis biaya dan manfaat, metode kuantitatif lah yang digunakan untuk memenuhi standard kelayakan suatu proyek.

D. Analisis Kelayakan Teknologi

Teknologi yang digunakan untuk memenuhi kebutuhan sistem yang dirancang ini perlu infrastruktur yang barik dan memenuhi standard dan syarat untuk berjalan secara baik. Maka pada Aplikasi Inventaris Gudang berbasis web ini digunakan perangkat seperti ditunjukkan pada Tabel 1 dan Tabel 2.

Tabel 1 Spesifikasi perangkat keras

\begin{tabular}{|c|c|c|}
\hline No & \multicolumn{2}{|c|}{ Perangkat Keras } \\
\hline 1 & Processor type & Intel (R) Core i3 \\
\hline 2 & Memory & 4GB DDR3 \\
\hline 3 & Hard drive type & 1TB serial ATA \\
\hline
\end{tabular}

Tabel 2 Spesifikasi perangkat lunak

\begin{tabular}{|c|l|l|}
\hline No & \multicolumn{1}{|c|}{$\begin{array}{c}\text { Perangkat } \\
\text { Lunak }\end{array}$} & \multicolumn{1}{|c|}{ Kegunaan } \\
\hline 1 & Windows 10 & Sistem Operasi \\
\hline 2 & Php, HTML & $\begin{array}{l}\text { Pembuatan Web } \\
\text { Sistem }\end{array}$ \\
\hline 3 & Sublime 3 & $\begin{array}{l}\text { Design Web } \\
\text { Sistem }\end{array}$ \\
\hline 4 & Google Chrome & Web Browser \\
\hline 5 & XAMPP & Web Server \\
\hline 6 & My SQL Server & Database Server \\
\hline
\end{tabular}

E. Analisis Kelayakan Sosial

Perancangan sistem terbilang tepat, karena hasil perancangan tersebut tidak memberikan pengaruh negatif pada 
lingkungan sosial.Tidak ditemukannya suatu pihak pada masyarakat yang terganggu dengan terciptanya sistem tersebut. Sistem tersebut mendorong lahirnya manfaat dan kegunaan khususnya bagi perusahaan.

\subsection{Tahap Analisa}

Pada tahap analisa dilakukan dengan berbagai langkah yang akan mempengaruhi pengembangan lebih lanjut dari aplikasi ini. Seperti analisa kinerja aplikasi, control aplikasi, efesiensi dan sebagainya.Pada proses perancangan sistem aplikasi tersebut, penyusun mengimplementasikan dengan bahasa pemrograman PHP dan MySQL dan merancang sebuah system atau aplikasi dengan berbasis website. Dalam hal ini software yang digunakan adalah XAMPP, sistem operasi windows, MySQL server, web browser (Google Chrome, Mozilla FireFox, Opera Mini). Software tersebut digunakan untuk mengakses aplikasi yang akan kita buat nantinya. Pengguna aplikasi ini adalah admin gudang dan pemakai bahan gudang

\section{Hasil dan Pembahasan}

Pada bagian ini, desain program sistem inventaris yang telah dianalisa dan dirancang akan diimplementasikan pada bentuk aplikasi.
Beberapa penerapan yang telah dirangkai menyesuaikan kebutuhan dalam analisa sebelumnya, dan menyesuaikan dengan kebutuhan perusahaan melalui halaman atau menu yang disediakan, seperti:

A. Halaman Menu Utama

Setelah melalukan login pada aplikasi inventaris dan melalui form login tersebut, maka redirect menuju halaman selanjutnya ialah halaman menu utama, dimana di halaman ini terdapat beberapa sub menu yang disediakan guna menunjang penggunaan aplikasi inventaris pada Gambar 1.

B. Halaman Data Barang

Pada halaman ini menampilkan detail data barang dan aksi yang dapat dilakukan admin guna menambah data, mengedit data, maupun menghapus data yang dilampirkan pada Gambar 2.

C. Halaman Input, Edit dan detail barang

Di halaman ini, digunakan sebagai halaman untuk memasukkan data barang baru, dengan menampilkan form sebagai medianya (Gambar 3), Serta ditampilkan kembali data tersebut pada menu data barang (Gambar 2) .

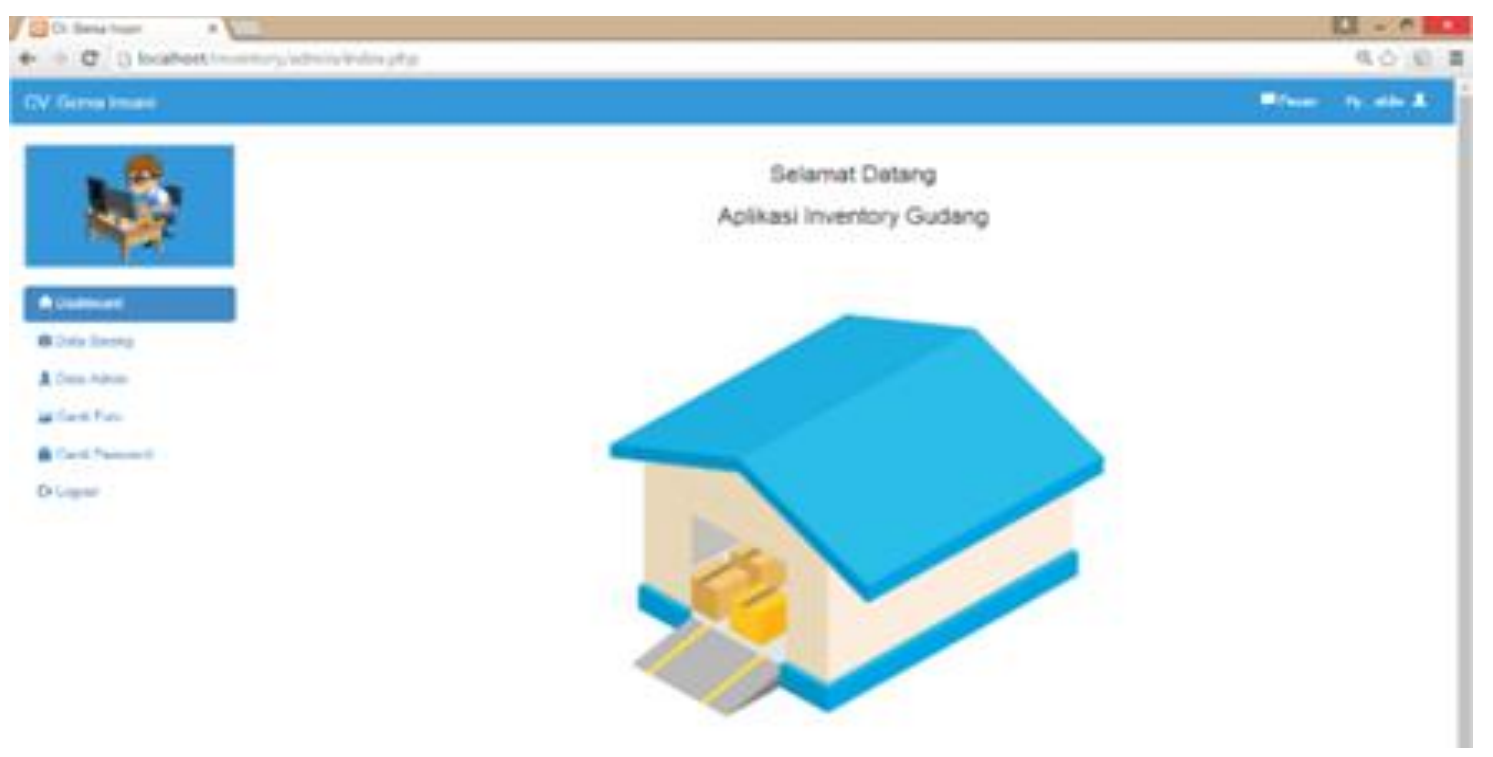

Gambar 1 Halaman Menu Utama 

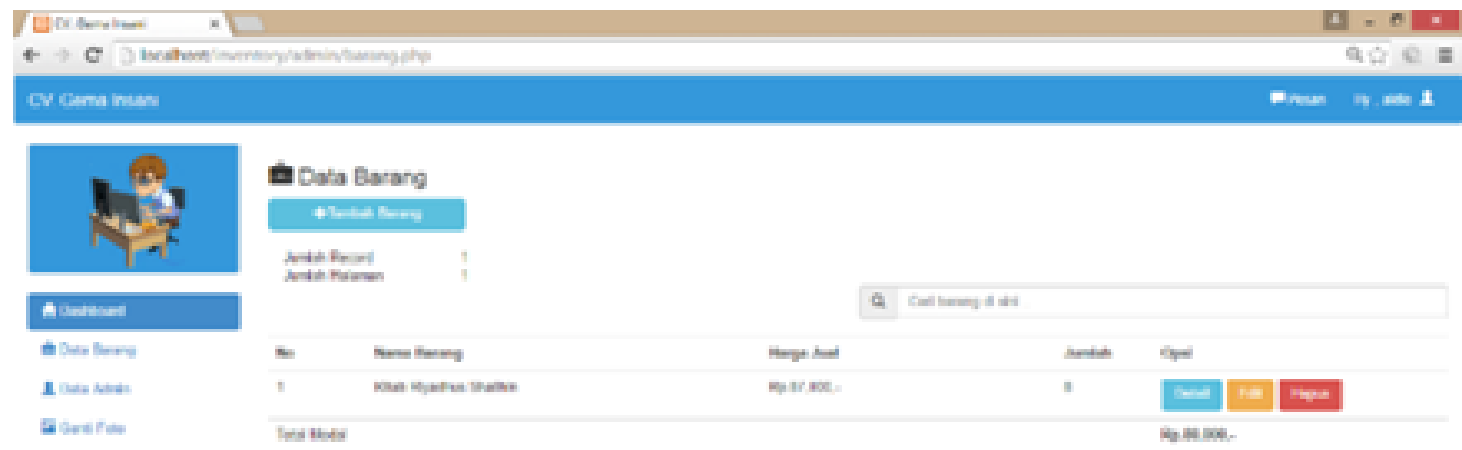

I num and

Irstusts arme.

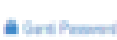

oroser

Gambar 2 Halaman Data Barang

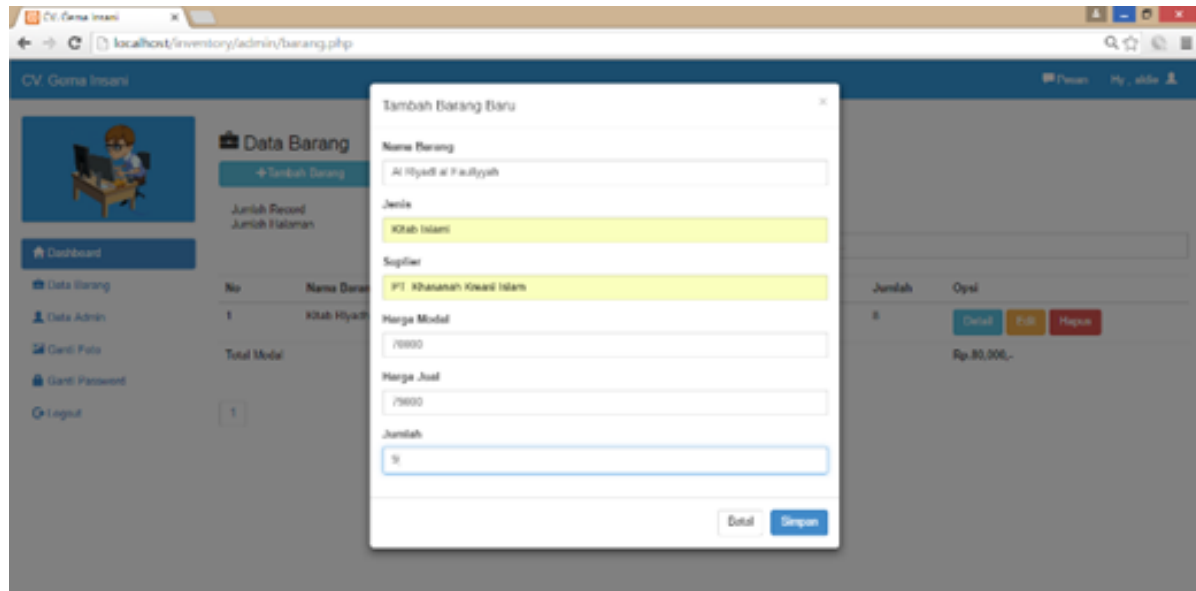

Gambar 3 Halaman Input Data Barang

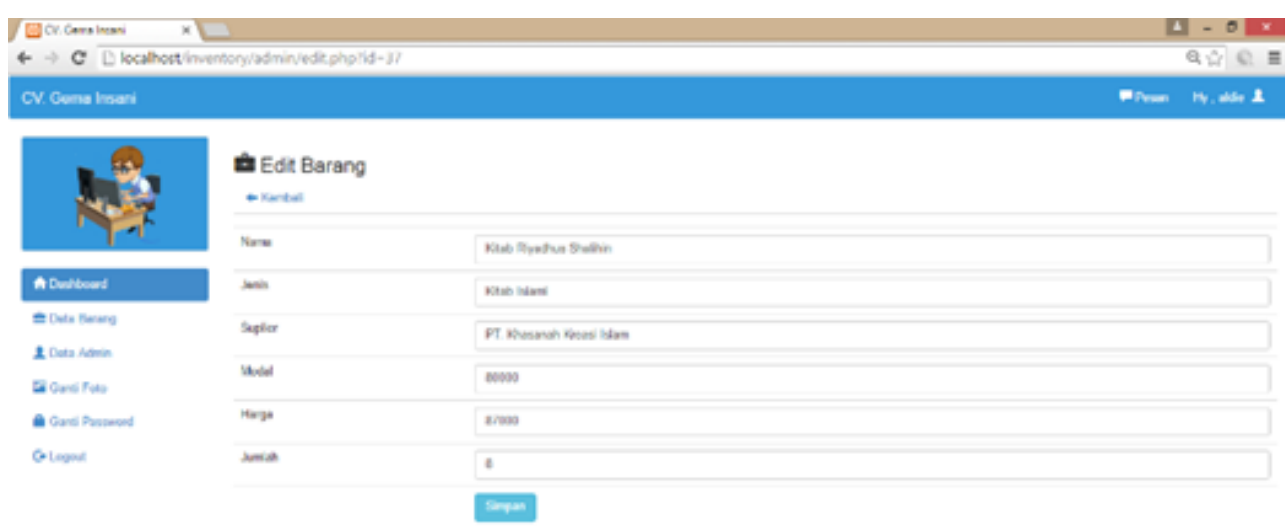

Gambar 4 Halaman Edit Data Barang 


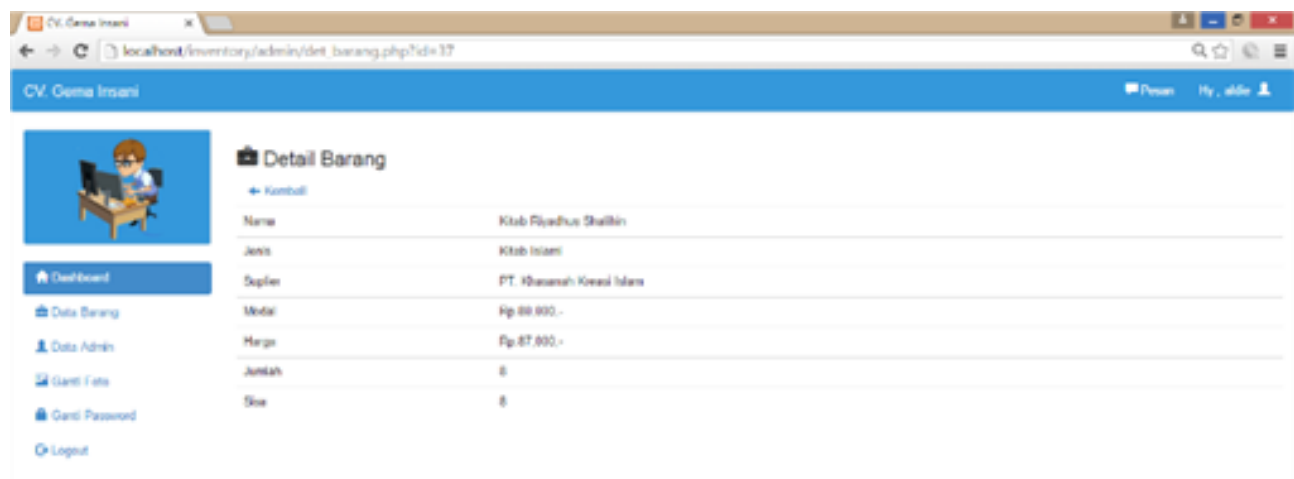

Gambar 5 Halaman detail barang

Lalu terdapat beberapa menu seperti menu edit data barang (Gambar 4) untuk mengubah data barang, apabila terdapat kesalahan dalam memasukkan dan data barang tersebut. Dan jika dipilih menu detail barang, akan ditampilkan halaman detail barang seperti pada Gambar 5.

\section{Kesimpulan}

Berdasarkan dilakukannya analisa dan perancangan perangkat lunak dalam inventaris barang tersebut ialah dapat diambil beberapa kesimpulan, yakni sebagai berikut:

1. Pada Sistem Inventaris Gudang yang dirancang dapat menolong kegiatan monitoring barang secara efisien dan efektif terutama dalam hal yang menyangkut stok masuk dan keluar barang, yang mana sebelumnya masih menggunakan Ms. Excel sebagai penunjang monitoring data inventaris gudang tersebut.

2. Aplikasi Inventaris Gudang tersebut juga dapat digunakan secara tepat, dengan menghemat beberapa biaya dan juga dalam hal waktu, pada sisi input data dan juga pencarian data, serta dalam monitoring data yang up-to-date.

3. Menggunakan metode waterfall yang mana dapat menjadikan data lebih terstruktur dan mudah digunakan.

\section{Saran}

Dari analisa dan perancangan yang dilakukan, penyusun sadar masih banyak sekali kekurangan mulai dari sistem yang dirancang maupun analisa yang keliru, maka dari itu penyusun memaparkan beberapa saran sebagai masukan pada penelitian lebih lanjut, seperti:
1. Dapat dikembangkan kembali pada sistem keamanan data pada aplikasi dan juga mekanisme kerja yang dapat diubah lebih fleksibel dengan memenuhi semua bidang perusahaan.

2. Dapat dikembangkan kembali interface yang lebih user friendly pada sistem yang dirancang

3. Dapat diperbarui dalam bahasa pemrograman yang digunakan dengan bahasa pemrograman website terbaru dengan beberapa kemudahan dalam mengembangkan kedepan serta beberapa fitur yang dapat mudah ditingkatkan pada sistem tersebut.

\section{Referensi}

Agusvianto, H. (2017). Sistem Informasi Inventori Gudang untuk Mengontrol Persediaan Barang Pada Gudang Studi Kasus : PT.Alaisys Sidoarjo. Journal of Information Engineering and Educational Technology, l(1), 40-46. doi:10.26740/jieet.v1n1.p40-46

Debiyanti, D., Sutrisna, S., Budrio, B., Kamal, A. K., \& Yulianti, Y. (2020). Pengujian Black Box pada Perangkat Lunak Sistem Penilaian Mahasiswa Menggunakan Teknik Boundary Value Analysis. Jurnal Informatika Universitas Pamulang, 5(2), 162-166. doi:10.32493/informatika.v5i2.5446

Khasani, G. P., \& Surjawan, D. J. (2016). Aplikasi Inventory Berbasis Web Pada PT Telkomsel NS Tasikmalaya. JuTISI (Jurnal Teknik Informatika dan Sistem Informasi) (eJournal), 2(3), 319-330. doi:10.28932/jutisi.v2i3.636

Pratala, C. T., Asyer, E. M., Prayudi, I., \& Saifudin, A. (2020). Pengujian White Box pada Aplikasi Cash Flow Berbasis Android Menggunakan Teknik Basis Path. Jurnal Informatika 
Universitas Pamulang, 5(2), 111-119. doi:informatika.v5i2.4713

Sari, A. O., \& Nuari, E. (2017). Rancang Bangun Sistem Informasi Persediaan Barang Berbasis Web dengan Metode Fast(framework For The Applications). Pilar Nusa Mandiri : Journal of Computing and Information System, 13(2), 261-266.

Syarif, I., \& Mustagfirin, M. (2019). Sistem informasi Inventory Barang Pada Apotek Sultan Menggunakan Metode First-In First-Out (FIFO). Jurnal Ilmiah Cendekia Eksakta, 4(2), 119-125. doi:10.3194/ce.v4i2.3056
Yulistina, S. R., Nurmala, T., Supriawan, R. M., Juni, S. H., \& Saifudin, A. (2020). Penerapan Teknik Boundary Value Analysis untuk Pengujian Aplikasi Penjualan Menggunakan Metode Black Box Testing. Jurnal Informatika Universitas Pamulang, 5(2), 129-135.

doi:10.32493/informatika.v5i2.5366 